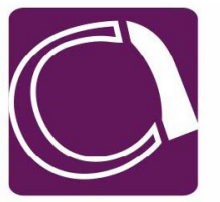
COVID-19 CRISIS. CASE STUDIES

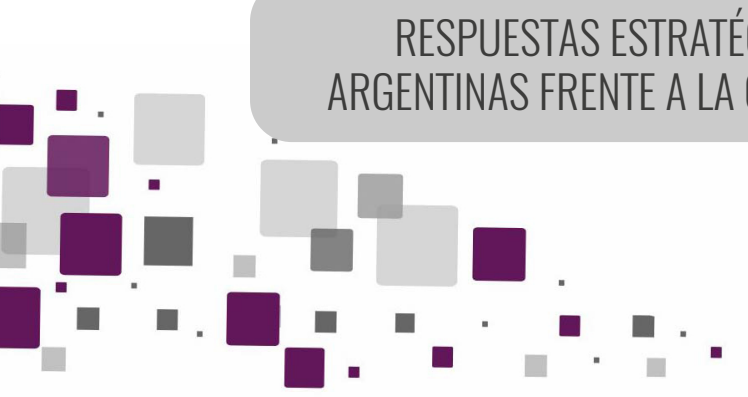

\section{RESPUESTAS ESTRATÉGICAS DE LAS EMPRESAS FAMILIARES ARGENTINAS FRENTE A LA CRISIS DEL COVID-19. ESTUDIO DE CASOS}

\section{Resumen / Abstract}

From the perspective of "familiness", this paper aims to understand the behaviour of family businesses in light of the pandemic caused by COVID-19. In the empirical study, a qualitative design was applied. Following Eisenhardt (1989) and Eisenhardt y Graebner (2007), a minimum of 4 (four) cases were selected to explore and report on the first responses in terms of organisational strategies implemented by family businesses located in a medium-sized municipality in Argentina and belonging to the agri-food chain. The results obtained make it possible to state that, in the face of this crisis, the participating organisations focused on evaluating external circumstances and adopting a series of immediate measures aimed at reducing expenses to maintain themselves, but also at growing towards new markets, relying on self-financing and strong family ties and relationships with third parties. The paper provides new evidence on the resilience of these companies in critical contexts, particularly those located in geographically delimited environments.

Keywords: COVID19; family businesses; familiness; organizational; strategies.

Desde la perspectiva de la "familiaridad", el objetivo de este trabajo es comprender el comportamiento de las empresas familiares frente a la pandemia originada por el COVID-19. En el estudio empirico se aplicó un diseño cualitativo; siguiendo a Eisenhardt (1989) y Eisenhardt y Graebner (2007), se optó por seleccionar un mínimo de cuatro casos con la finalidad de explorar e informar acerca de las primeras respuestas en términos de estrategias organizacionales implementadas por empresas de naturaleza familiar, ubicadas en un municipio de tamaño intermedio de Argentina y pertenecientes a la cadena agroalimentaria. Los resultados obtenidos permiten manifestar que, frente a esta crisis, las organizaciones participantes se enfocaron en evaluar las circunstancias externas y adoptar una serie de medidas inmediatas orientadas a reducir gastos para mantenerse, aunque también en el crecimiento hacia nuevos mercados, apoyándose en el autofinanciamiento y los fuertes vínculos familiares y con terceros. El trabajo proporciona nueva evidencia sobre la capacidad de recuperación de estas empresas en contextos críticos, en particular aquellas ubicadas en entornos geográficamente delimitados.

Palabras clave: COVID-19; empresas familiares; familiaridad; organizacionales; estrategias.

\section{- SILVIA CORRAL}

https://orcid.org/0000-0002-9362-1492

silvia.corral@econ.unicen.edu.ar

\section{- Ma. CLAUDIA D'ANNUNZIO}

https://orcid.org/0000-0002-0666-2916

claudia.dannunzio@econ.unicen.edu.ar

\section{- ALFREDO RÉBORI}

https://orcid.org/0000-0002-3029-456X

decano@econ.unicen.edu.ar

Facultad de Ciencias Económicas. Universidad Nacional del Centro de la Provincia de Buenos Aires. Argentina. 
and unexpected events (Sabatino, 2016).

Then, in the third section, a qualitative and narrative methodology is proposed to allow us to describe and analyse the results based on the meanings individuals attribute to the lived experience and considering the context in which they occurred. Visualising the "how" of the phenomenon offers a better understanding of the different circumstances that occur in the critical process. In a later section, the main results of the analysis are presented, and finally, a discussion and conclusion section is offered.

\section{Theoretical Framework}

\section{Crisis and Strategic Alternatives}

In the organisational field, a crisis can be defined as the interruption of the expected development due to the emergence of abnormal events that the parties perceive as threatening to their continuity, which is why the urgent issue becomes how to restore the balance (Lalonde and Roux Doufort, 2010; Roux-Dufort, 2007).

Different types of crises pose specific problems that need to be identified since common features could be detected to try and manage them. In this sense, linked to its conceptualisation, the need to establish a classification arises intending to allow a better practical analysis of the crisis (Gundel, 2005).

In principle, disruptions should not only be recognised as such when they are caused by exceptional events, as they can also have a processual nature (Roux-Dufort, 2007). Accordingly, and in the face of different proposed typologies, Williams et al. (2017) broadly distinguish between crisis as an event and crisis as a process. While the former refers to that unexpected or unforeseen situation that gives little room for developing a response-and, at the same time, stakeholders may perceive it as putting the viability of the organisation at risk-crisis as a process is revealed as a series of events that are triggered over time and with which organisations interact. It is necessary to interpret these events in their environment to respond at different stages.

Undoubtedly, the COVID-19 crisis fits the concept of crisis as an event since it is an unplanned and unnoticeable event, which shows, in principle, the inability to consider all the associated and potential risks (Rosenthal, 2003); therefore, the development of an effective response to deal with these unexpected and disruptive situations will depend on the adaptive and proactive behaviour of the people who make up a system. In the case of the organisational system, the responses become necessary when noticing that the established structures and routines are insufficient (Boin, 2009; Boin and McConnell, 2007). Thus, this event leads organisations to demonstrate their capacity for resilience, that is, to face the unexpected by developing specific, and even transformative, responses to capitalise on these threats in favour of their survival and avoid those non-adaptive tendencies (Lengnick-Hall et al., 2011). In general, resilience is not conceived as a static attribute but as the result of processes that collaborate in flexibly maintaining available resources to facilitate contingent adaptation in the face of adversity (Meneghel et al., 2013). However, when resources are limited, they condition the ability of companies to respond promptly to these critical events; similarly, institutional conditions and stakeholder support are external factors that can favour or hinder their development (Halkos et al., 2018).

Starting from the argument that both concepts, crisis and resilience, are closely related, Wenzel et al. (2020) review the literature to finally synthesise the four possible strategic responses of companies in the face of a critical scenario:

- Downsize: this is a widely observable and even unavoidable strategic position that aims to reduce costs, assets, products, product lines and overhead. It intends to reduce the scope of a company's business in the short term to achieve its survival. Its long-term viability is debatable, as continued downsizing can lead to the deterioration of valuable resources, capabilities, and even the organisational culture.

- Persevere: this consists of maintaining the status quo. It can be an effective response, essentially linked to the availability of resources, both internally and externally. For the medium term, it can be considered a strategic and viable response.

- Innovate: this implies taking advantage of those windows of opportunity that open up amid the prevailing uncertainty 
preserve their socioemotional wealth (a term coined by Gómez-Mejía et al., 2007, p. 106). Thus, these companies, faced with the risk of losing or endangering family control, financial resources and, consequently, the welfare of the human resources inside them and future generations, would adopt a conservative position, with a greater emphasis on the survival goal (Miller and Le Breton-Miller, 2006; Naldi et al., 2007).

However, as argued by Faghfouri et al. (2015), although in the long run, these behaviours represent a threat to the continuity of the company through generational transfer, it should be clarified that the position towards risk could vary depending on whether the first generation or later generations are in charge (Chrisman et al., 2013; Muñoz-Bullon et al., 2018; Wang and Poutziouris, 2010).

Specifically, and as anticipated in the initial section, this paper aims to interpret the behaviour of the family business in the face of the COVID-19 crisis from the perspective of familiness, a concept applicable only to these companies (Frank et al., 2010; Pearson et al., 2008) as a result of the identification of its members with the business (Cabrera-Suárez et al., 2014; Zellweger et al., 2010) and which, encompassing the consequences of family involvement in terms of ownership, management and intergenerational intention (Chrisman et al., 2005), collectively impacts their strategic choices and continuity (Chrisman and Patel, 2012; Chrisman et al., 2013; Sharma et al., 2014).

\section{Methodology}

\section{Research Design}

A qualitative approach is used by applying the research strategy based on case studies due to the researchers' interest in answering a central question: How did family businesses in the municipality of Tandil respond and adapt to the situation caused by COVID-19? A second criterion that led to the choice of this methodology is the possibility of approaching in greater depth a recent event for which there is no historical information available-which is the case of this pandemic - to investigate it in the actual context in which it occurred. It is also a phenomenon that cannot be manipulated experimentally. The case study allows us to have data provided by the actors involved to be able to find in a subsequent analysis both relationships between the results and the theory developed (analytical generalisation) and possible explanations between causes and effects (Eisenhardt and Graebner, 2007; Koivu and Hinze, 2017; Yin, 2003). On the other hand, it has been the methodology suggested for research in the field of business organisations management (Cepeda and Martin, 2005; Fassio, 2018; Larrinaga and Rodriguez, 2010) and, in a specific way, for the study of companies of a family nature for providing an approach that would allow interpreting the heterogeneity and complexity inherent to these organisations (De Massis and Kotlar, 2014; Nordqvist et al., 2009).

\section{Unit of Analysis}

In order to carry out the fieldwork, four companies located in Tandil, a medium-sized town in the southeastern region of the Province of Buenos Aires, Argentina, were selected. It should be clarified that the cases have been selected intentionally yet considering the following criteria so that they could cover the phenomenon of interest (Yin, 2003) and meet the purpose pursued in applying this methodology (Koivu and Hinze, 2017): i) that it is a family business, in the sense that it has majority family ownership and at least one representative of the family participates in the management or administration; ii) that the company develops its activity in a representative sector of the local economy. Within the framework of these criteria, FBs linked to the agri-food chain and belonging to the manufacturing industry link (food: two of them engaged in the production of sausages and the other two in the production and sale of food and ice-cream) were selected. In this sense, the selection of the case studies is deliberate, since the research has a theoretical, not statistical, foundation; that is to say that the researchers have considered them adequate to illustrate and extend the theoretical relationships (Eisenhardt, 1989; Eisenhardt and Graebner, 2007; Yin, 2003).

\section{Contextualisation and Case Description}

The selection of the context to which the case studies belong is based on the fact that the agrifood market has had a particularly remarkable and sustained growth in the region, being the district of Tandil one of the main engines of this performance (Lódola et al., 2013). Within the Province of Buenos Aires, the district of Tandil is configured as Medium 
with constant and sustained growth, tripling its installed production capacity by moving in 2010 to the city's Industrial Park. Currently, it is in a new turning point: obtaining the national sanitary permit, which will allow them to leave the province.

- CASE FB2: 1st generation family business, with a desire for growth and family continuity; for this reason, the children are managing their own ventures but are still linked to the business. It started its activity in 2015 as a cafeteria with its own bakery. A year later, it became a restaurant, brewery and cafeteria, offering cuisine all year round, country breakfasts, and natural snacks.

- CASE FB3: family business founded in 1992 in response to the collapse of slaughterhouses and livestock consignment houses and the need to sell the overwintered steers. With the incorporation of the second generation, in 2003, the company ventured into the commercial activity with the sale of meat and sausages of their own production, innovating in the market based on the recipes of the founding couple, who always lived in the countryside.

- CASE FB4: family business dedicated to the semi-industrial manufacture of ice cream. It started its activity in 1976 and has managed to expand in the locality and the southeast of the Province of Buenos Aires through the franchise model. Currently, in the administration and management of the company, there are members of the 2 nd and 3rd generations. Concerning its beginnings, the company has diversified its offer by making different products, besides offering catering services for events and cafeteria services at the points of sale.

\section{Sources of Information, Data Collection and Analysis}

For data collection, semi-structured interviews were conducted in person by the researchers themselves. The questionnaire used in the research by Kraus et al. (2020), which has been the trigger for this study, was adapted. The interviews include those family members who held a management position in the company in addition to being owners. The interviewsten in total-were conducted in their own work environments between July 19 and August 19, 2020, a period in which the locality of residence of the companies was in phase 5, called "the new normality", in which a greater circulation of the population was possible and careful and sustained hygiene habits replaced the restrictions of the previous stages. The duration of the interviews was about one hour, and a record was kept through audio and notes by the interviewers/researchers. The visit to the facilities of each company favoured an informal communication between interviewers and interviewees, which were used, together with the observations carried out, as additional sources of information to interpret the data collected through the interview. We also sought to integrate evidence from other sources, such as press articles published about the companies, training workshops through a digital platform in which the first author participated as coordinator, as well as company websites. Finally, the responses obtained were transcribed verbatim. The permanent point of reference for examining the data was the theoretical framework; firstly, to identify themes and categories in their contents, the information was gathered, and an analysis of the discourses in each case was carried out. The notes obtained through observation and additional sources were incorporated into the analysis. Then, convergence between the cases was sought (Yin, 2003), a phase that required constant interaction between theoretical preconceptions and inductive reasoning, influenced by the results that emerged as the data was analysed.

From the transcription of the interviews conducted, certain aspects emerge to be considered in an attempt to understand how family SMEs in the food sector responded to the COVID-19 crisis. In the following section, these are organised and presented in four axes to facilitate their interpretation and analysis, and exemplary excerpts are presented.

\section{Results Achieved}

\section{Immediate Measures}

First of all, the interviewees coincided in recognising a high level of affectation of the activity and its impact in terms of internal business factors:

"When the pandemic started, sales dropped by $25 \%$... the restaurants that used to buy from me in Buenos Aires were closed to the public, and they couldn't pay what they owed". (FB1)

"We used to work a lot with the delivery 
system to technology companies and offices in the area; we went from 120 daily deliveries to zero when they started to do home office... We started to deliver as take-away, but it was really hard: three or four deliveries ${ }^{2}$ a day..." (FB2)

"Here [in the store], I was affected by $90 \%$. In the case of the field, the level of affectation was much lower. Yes, in terms of the sale of bulls and exhibitions because they can't be held". (FB3)

"There were all kinds of complications: reception of merchandise, deliveries... Obviously, everything related to gastronomy was reduced to zero and, in retail, we only closed delivery stores to concentrate our efforts on the others and be able to attend to a greater number of deliveries at the same time". (FB4)

A first response to deal with this unexpected situation was to control unnecessary expenses and, more worryingly, to consider strategies to avoid downsizing. At this point, the employers acknowledged their adherence to the Emergency Assistance Program for Work and Production (or government aid ATP) to pay salaries. In this way, they sought to reorganise and readjust the production staff:

"The sale had become so depressed that we were able to set up three working groups. Each group was headed by one of the brothers"; "At first, we agreed on a Contingency Plan with the personnel, who were going to work 15 days on and off... And everyone agreed. So, I would like to highlight the good predisposition of everyone, the commitment. But luckily, it was not necessary because the ATP came out"; "And we received a third of our salary while it was necessary... we worked in all the roles... and we put in the hours that we had to put in". (FB1)

"In the beginning, we had to organise workgroups... and work hard with people to apply the whole protocol system. The staff was our priority; everyone needed to get paid on time. And, sometimes, we delayed paying a supplier to deal with it later." (FB4)

In the case of FB2, given the seasonal profile of the activity, appealed not to renew the contracts that expired that month and readjust its stable staff and, like FB3, stressed the need to maintain the business with the minimum staff required:

"You have no choice today but to stay only with the right staff... the first employees are still
Año 10 | No 19 Enero - Julio 2022 | ISSN 2314 - 3738

Silvia Corral | Mà. Claudia D'Annunzio | Alfredo Rébori

there... but the fear today is to employ one more and have them go back to phase 1". (FB2)

This brought certain tasks and functions reorganisation, as evidenced by the business owners themselves:

"My pastry chef went from pastry chef to being at the checkout counter to waitressing. But everyone realised they had to learn". (FB2)

"I didn't have to lay people off because I don't have many... Because one is already so punished from so many previous crises that growth is minimal... I don't take on more people". (FB3)

\section{Financial Management}

Although the interviewees recognised having "resources" or their own financial capital to face the situation initially, having taken loans at preferential rates, which could be paid off, or having paid off previous debts by selling stock, they considered it necessary to reduce expenses to avoid getting into debt in a context of extreme uncertainty:

"From working well, from one day to the next, zero turnover; this has changed the way we buy, the way we sell, everything. We don't sell or buy anymore with the ongoing business account... it was our own decision because the suppliers keep giving it to us... but we are worried about closing down again..." (FB2)

"...we had an extra production because of the Day of Remembrance for Truth and Justice and the "Masticar" Fair... that made us work at 25\% of our installed capacity"; "...at that time, health contingency plans were made but also in financial terms: lengthening payment terms, regarding stock consumption... we started to take on debts on our stock and in a very associative way with our suppliers... in fact, we owed suppliers, and our clients owed us"; "we have the culture of taking credits, as long as they are accessible... we do not distribute dividends either; because, from the financial point of view, the company is healthy..." (FB1)

"What I had managed to save the year before was part of what was used to pay suppliers. I only owed one supplier. Because, as a result of previous crises... if there's no money, I don't buy. We had capital, we put in the hours, and we had a lot of commitment from the [employees] working for us". (FB3) 
"Fortunately, we did not suffer shortages because we had stock of finished products and raw materials. We made use of the ATP for two months and, later, we took credits to face the payment of salaries... Always thinking positively and that this was going to end and we would be able to face this normally... And I highlight the support of the people. Nobody questioned that while others were out of work, we had to work". (FB4)

\section{Communication}

Communication with the staff was constant, and the channel used was informal in all cases (WhatsApp). This modality is seen as the most appropriate one for family SMEs, with few employees and simple organisational structures. In this way, communication with suppliers was also intensified and, towards the market, the use of social networks and WhatsApp Business was reinforced:

"...we were already working with social media but, after the pandemic, we worked much more on this... we dedicated a lot of time in our house to improve the image, and the visibility was much bigger... and then, the new clients that arrive through social media never cease to surprise you". (FB1)

The interviewees also highlight an intensification of ties with other business owners in the industry:

"With... [other firms] we are all family businesses... the reality we share is enormous... Before the DOT (Denomination of Origin, Tandil), we already had many dialogues and ties... if we lack things, we barter, we help each other... we work together" (FB1)

"...in the gastronomic group, there was a lot of communication. And it is like we are very present now to form the Association of Tourism and Gastronomy... there is also more contact with the Chamber of Commerce. We are also in the group "Comerciantes Unidos", which was born out of dissatisfaction with the actions of the Chamber of Commerce, which is more concerned with big business than with the sellers... But now you see that 400 sellers formed "Comerciantes Unidos"... with COVID, they have found realities that they did not know... and these groups were formed to take actions that are bearing fruit. And they have also developed local platforms for delivery". (FB2)

"...with the competitors, we were able to come together and make different presentations to the municipality, since ice-cream shops were not seen as an activity..." (FB4)

Specifically, FB3 and FB4 emphasise how they interacted with their main clients or partners in this extreme situation:

"Contact was intensified, not at the level of work but of support... I am a supplier, and I cannot go out and give them fierce competition... I try to generate actions with them... I tried to help them with ideas, and l even helped them to sell because it was a huge blow... psychologically". (FB3 concerning the stores selling regional products)

"Maintaining ties is very important because they are medium- and long-term relationships. We had to work hard to support the franchises... some cities would not allow them to open, and we went there to get the permits". (FB4 on the situation generated to franchisees from other locations)

\section{Sales}

The new sales channels that have emerged from this situation are appreciated in all cases since they "helped to solve part of the problem" (FB1). On a different note, there is optimism regarding the possibility of deciding to expand the market and even export once the authorisation by the national health agency (SENASA) is obtained, and what has been learned is highlighted:

"From this crisis, we learned sanitation protocols, and the idea is to sustain them... and going deep on social media... the crisis allowed us to explore digital commerce and delivery" (FB1), and "with the intensification of this channel [delivery] to try to remedy the forced night reduction of the restaurant service partly". (FB2)

"You are comfortable with one market, but you shouldn't neglect others... because it happens again and you have to reinvent yourself... or reinvent the markets". (FB3)

"The delivery allowed us always to be there... we lost the counter sales and we had to reconfigure it; we also had to work a lot on franchises... And with all the protocols of the case, as distributors, we went out to neighbouring cities. We were already on some platforms like [mentions a virtual platform], and we advanced in developing attention by WhatsApp, Facebook and Instagram. Now we are finishing putting together an app... The communication changed a little with 
the franchises and with the consumers... I think the digitalisation of meetings is useful... but the face-toface part for some issues is determinant". (FB4)

Two salient aspects emerge here: the first one is the ability of family businesses to use and reuse relationships established from long-lasting personal ties. In contrast, the second one involves moving forward with a decision to grow into new markets/services that could be positioned as an innovative response involving strategic renewal. Regarding the possible success of the response to the shock, some studies indicate that a persistence strategy may encounter limitations if the crisis lasts too long. In this sense, given the resource-based limits to persevere over time, it can be argued that innovating may be increasingly valuable, if not inevitable, to maintain a steady long-term survival if the crisis lasts for a more extended period and attention is paid to exploring alternative sources of income. What is critical here is the decision to expand the market outside the Province of Buenos Aires and even export; decisions that will imply obtaining additional resources and higher risk.

\section{Discussion and Conclusions}

The work carried out has allowed us to access relevant information to understand the behaviour of family businesses that develop their activity within the agri-food chain in a medium-sized municipality of Argentina in the face of the COVID-19 pandemic. This situation adds to structural imbalances and a general recessionary scenario of several years.

The empirical development shows that the companies that participated in the study opted in the first place to evaluate the external circumstances and adopt a series of immediate measures aimed at reducing unnecessary expenses. However, they mainly focused on how to maintain and sustain a decision to grow into new markets. This immediate implementation strategy was supported by the search for self- financing. At the same time, the avoidance of downsizing as an alternative illustrates how family businesses contribute to employment stability. To this effect, the interviewees themselves highlighted the centrality of those resources distinctive to family businesses, intangible in nature and generated from strong personal relationships and a shared vision and purpose. This identification, interpersonal support, and sense of solidarity towards employees lead family businesses to prioritise their claims. Therefore, and in line with the theoretical framework on familiness, this paper would allow anticipating that the commitment of the human capital that makes up small and medium family businesses, the patient financial capital and the ties they maintain with third parties outside the family (employees, customers, and suppliers) became strategic resources to face this pandemic. These findings are consistent with studies suggesting that not all the resources and capabilities are equally important to persevere in a crisis; thus, leveraging firm-specific core competencies is "the strongest bastion against an adverse event" (De Carolis et al., 2009, p. 157).

Moreover, two aspects emerging from the fieldwork are the following: i) the firm adherence to the Emergency Assistance Program for Work and Production (or government aid known as "ATP") to cope with the payment of wages initially allows to enhance the positive role of institutions that help mitigate the disruptive effect of a shock by providing companies with access to capital and information (Stieglitz et al. 2016); ii) the integration at the micro and meso local level seems to play an important role in mitigating the impact of the crisis in that, in the absence of certainty about the likely duration of COVID-19-related disruptions, those affected by the closure held meetings between local firms and institutions to keep businesses active. Thus, the search for consensus at the collective level regarding the actions to respond to the crisis laid the foundations for action in the face of the situation. In this sense, general recognition of the difficulty of the situation is identified, as well as the necessary support and accompaniment through networks formed between companies and with intermediate actors and post-pandemic virtual platforms. This result advances the understanding of the literature related to micro-territorial behaviours of family businesses (Maskell, 2001).

In such a context, communication manifests itself as a central management tool. It has a strategic value for the companies: the adverse situation allowed them to visualise opportunities to strengthen their businesses, their image or their market reputation (as evidenced by the launch of new products and services to sustain sales), and to apply new alternatives to communicate and sell their products. This led to develop and implement a communication plan during the crisis, which means that, in this scenario of great uncertainty, they did not seek a quick way out but 
tried to apply sustainable solutions for the medium and long term basically in three areas: institutional communication, market communication-in terms of products/services - and internal communication, being in the latter where they place greater emphasis to socialise the protocol of action.

This allows us to point out that, although the Family Businesses in our study did not have strategic contingency programs for an extreme crisis such as the one generated by COVID-19, they were able to devise quick operational solutions by deploying idiosyncratic resources-resulting from family ownership and participation in the company-that allowed them to rethink previous plans, position themselves in more favourable conditions to manage the impact of an external variable such as the one mentioned above and persevere, preventing them from evolving towards a situation of internal crisis of their own.

\section{Contributions and Limitations}

In line with the previous study by Kraus et al. (2020), carried out in the context of five European countries, our work contributes to the field of strategic management and, specifically, to the study of how to manage a crisis within the framework of the strategic responses proposed from the theory, reflecting on how Argentinean family businesses belonging to the agri-food chain are affected by the current COVID-19 pandemic. In addition, it illustrates the first responses to the impact in terms of organisational strategies and provides new evidence on the resilience of Argentine family businesses in the face of adversity. In addition, the perspective of familiness adopted in this research contributes to the understanding of the behaviour of these companies in a critical context, from a particular dynamic that favours the strengthening of their social capital through the maintenance of ties with customers, suppliers and employees. Faced with an event of this magnitude, which threatens employment levels and deeply rooted relationships based on trust between a family business and its community, companies prioritised the claims of their employees. However, we believe that the COVID-19 pandemic has exposed pre-existing problems in the Argentine labour market and presents an opportunity for policymakers to define and describe our country's needs in this regard. In relation to this, it is argued that this positive effect on job retention could disappear if the economic crisis is prolonged; therefore, greater policy involvement in public assistance to these firms is crucial to contribute to the post-crisis recovery.

As for the most significant limitation, we recognise that the study takes a small sample focused on one sector of business activity, which poses an evident difficulty in making generalisations. Future research should broaden the context of analysis to reach family businesses in other sectors or even consider the responses elaborated by FBs from other countries, a strategy that may highlight different aspects related to the influence of the family in the business. Our study has not sought to delve into the elements that foster these companies' acquisition, development, and accumulation of adaptive capabilities. Finally, we state that the ideas presented based on the evidence derived from the process of our research intend to stimulate the academic studies necessary for this field, as well as the development of specific programs and collective efforts to encourage Family Businesses because we visualise the need to facilitate their actions and to develop and evaluate strategies of advice and institutional support as a way to provide them with permanent concrete support and not only during a crisis.

\section{References}

Arancibia Obrador, M. J. (2016). La importancia de las denominaciones de origen e indicaciones geográficas para la identidad país [The importance of denominations of origin and geographical indications for country identity]. Revista Iberoamericana de Viticultura, Agroindustria y Ruralidad, 3(8). https:// www.redalyc.org/pdf/4695/469546449013. pdf

Berrone, P., Cruz, C. y Gómez Mejía, L. (2012). Socioemotional Wealth in Family Firms: Theoretical Dimensions, Assessment Approaches, and Agenda for Future Research. Family Business Review, 25(3), 258-279. https://doi. org/10.1177/0894486511435355

Boin, A. (2009). The new world of crises and crisis management: Implications for policy making and research. Review of Policy Research, 


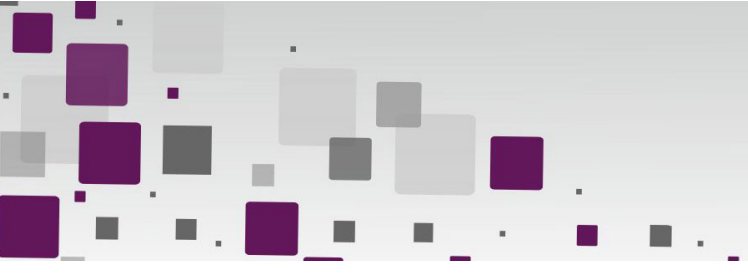

26(4), 367-377. https://doi.org/10.1111/ i.1541-1338.2009.00389.x

Boin, A. y McConnell, A. (2007). Preparing for critical infrastructure breakdowns: The limits of crisis management and the need for resilience. Journal of Contingencies and Crisis Management, 15(1), 50-59. https://doi.org/10.1111/j.14685973.2007.00504.x

Cabrera-Suárez, M. K., Déniz-Déniz, M. d. L. C. y Martín-Santana, J. D. (2014). The setting of non-financial goals in the family firm: The influence of family climate and identification. Journal of Family Business Strategy, 5(3), 289-299. https://doi.org/10.1016/j. jfbs.2014.05.003

Carnes, C. M. e Ireland, D. (2013). Familiness and Innovation: Resource Bundling as the Family. Entrepreneurship Theory and Practice, 37(6), 1399-1419 https://doi.org/10.1111/ etap.12073

Cepeda, G. y Martin, D. (2005). A review of case studies publishing in Management Decision. Guides and criteria for achieving quality in qualitative research. Management Decision, 43(6), 851-876. https://doi. org/10.1108/00251740510603600

Chrisman, J. J., Chua, J. H. y Steier, L. (2005). Sources and consequences of distinctive familiness: An introduction. Entrepreneurship Theory and Practice, 29(3), 237-247 https://doi. org/10.1111/j.1540-6520.2005.00080.x

Chrisman, J. J. y Patel, P. C. (2012). Variations in R\&D investments of family and non-family firms: behavioral agency and myopic loss aversion perspectives. Academy of Management Journal, 55(4), 976-997. https://doi. org/10.5465/amj.2011.0211

Chrisman, J. J., Sharma, P., Steier, L. P. y Chua, J. H. (2013). The influence of family goals, governance, and resources on firm outcomes. Entrepreneurship Theory and Practice, 37(6), 1249-1261. https://doi. org/10.1111/etap.12064
Año 10 | No 19 Enero - Julio 2022 | ISSN 2314 - 3738

Silvia Corral | Ma. Claudia D’Annunzio | Alfredo Rébori

De Carolis, D. M., Yang, Y., Deeds, D. L. y Nelling, E. (2009). Weathering the storm: The benefit of resources to high-technology ventures navigating adverse events. Strategic Entrepreneurship Journal, 3(2), 147-160. https://doi.org/10.1002/sej.68

De Massis, A. y Kotlar, J. (2014). The case study method in family business research: Guidelines for qualitative scholarship. Journal of Family Business Strategy, 5(1), 15-29. https://doi.org/10.1016/i.jfbs.2014.01.007

Donato, V. N. (2016). Informe 2015-2016: evolución reciente, situación actual y desafíos para 2017 (1 $\underline{a}$ ed.) [Report 2015-2016: Recent Developments, Current Situation and Challenges for 2017 (1st ed.)] Fundación Observatorio Pyme.

Eisenhardt, K. M. (1989). Building Theories from Case Study Research. Academy of Management Review, 14(4), 532-550. https://doi.org/10.5465/amr.1989.4308385

Eisenhardt, K. M. y Graebner, M. E. (2007). Construction of theories from cases: opportunities and challenges. Academy of Management Journal, 50(1), 25-32. https:// doi.org/10.5465/amj.2007.24160888

Faghfouri, P., Kraiczy, N., Hack, A. y Kellermanns, F. (2014). Ready for a crisis? How supervisory boards affect the formalised crisis procedures of small and medium-sized family businesses in Germany. Review of Management Science, 9(2), 317-338. https://doi.org/10.1007/ s11846-014-0158-0

Fassio, A. (2018). Reflexiones acerca de la metodología cualitativa para el estudio de las organizaciones [Reflections on Qualitative Methodology for the Study of Organizations]. Ciencias Administrativas, (12), 028. https:// doi.org/10.24215/23143738e028

Foro Económico Mundial. (2017). The Global Competitiveness Report 2017-2018. https://es.weforum.org/reports/the-globalcompetitiveness-report-2017-2018 
Frank, H., Lueger, M., Nosé, L. y Suchy, D. (2010). The concept of "Familiness": Literature review and systems theory-based reflections. Journal of Family Business Strategy, 1(3), 119-130. http://dx.doi.org/10.1016/j. jfbs.2010.08.001

Gómez-Mejía, L., Haynes, K., Nuñez, M., Jacobson, K. y Moyano, J. (2007). Socioemotional wealth and business risks in familycontrolled firms: Evidence from Spanish olive oil mills. Administrative Science Quarterly, 52(1), 106-137. http://dx.doi.org/10.2189/ asqu.52.1.106

Gómez-Mejía, L., Makri, M. y Lazarra Quintana, M. (2010). Diversification Decisions in FamilyControlled Firms. Journal of Management Studies, 47(2), 223-252. http://dx.doi. org/10.1111/j.1467-6486.2009.00889.x

Gundel, S. (2005). Towards a new typology of crises. Journal of Contingencies and Crisis Management, 13(3), 106-115. https://doi. org/10.1111/j.1468-5973.2005.00465.x

Habbershon, T. G. y Williams, M. (1999). A resource-based framework for assessing the strategic advantages of family firms. Family Business Review, 12(1), 1-25. https://doi. org/10.1111/j.1741-6248.1999.00001.x

Halkos, G., Skouloudis, A., Malesios, C. y Evangelinos, K. (2018). Bouncing back from extreme weather events: some preliminary findings on resilience barriers facing small and mediumsized enterprises. Business Strategy and the Environment, 27(4), 547559. https:// doi.org/10.1002/bse.2019

International Family Enterprise Research Academy (IFERA). (2003). Family Businesses Dominate: International Family Enterprise Research Academy (IFERA). Family Business Review, 16(4), 235-240.

Koivu, K. y Hinze, A. (2017). Cases of convenience? The divergence of theory from practice in case selection in qualitative and mixedmethods research. Political Science \& Politics, 50(4), 1023-1027. https://doi.org/10.1017/ $\underline{\text { S1049096517001214 }}$
Kraus, S., Clauss, T., Breier, M., Gast, J., Zardini, A. y Tiberius, V. (2020). The economics of COVID-19: Initial empirical evidence on how family firms in five European countries cope with the corona crisis. International Journal of Entrepreneurial Behaviour \& Research, 26(5), 1067-1092. http://dx.doi. org/10.1108/IJEBR-04-2020-0214

Lalonde, C. y Roux-Dufort, C. (2010). Crisis management in institutional healthcare settings: From punitive to emancipatory solutions. Organization Development Journal, 28(1), 19-36.

Lan, D. (2017). La industria en Tandil: datos generales del relevamiento industrial, 2013. [Industry in Tandil: General Data from the Industrial Survey, 2013] Universidad Nacional del Centro de la Provincia de Buenos Aires. www.academia.edu/36034990

Larrinaga, V.y Rodríguez, L. (2010). El estudio de casos como metodología de investigación científica en dirección y economía de la empresa. Una aplicación a la internacionalización [The case study as a scientific research methodology in management and business economics. An application to internationalization]. Investigaciones Europeas en Dirección y Economía de la Empresa, 16(3), 3152. https://doi.org/10.1016/S11352523(12)60033-1

Lengnick-Hall, C. A., Beck, T. E. y Lengnick-Hall, M. L. (2011). Developing a capacity for organisational resilience through strategic human resource management. Human Resource Management Review, 21(3), 243-255. $\quad$ https://doi.org/10.1016/i. hrmr.2010.07.001

Lódola, A., Brigo, R. y Morra, F. (2013). Economía de los gobiernos municipales. Teoría y aplicaciones a la Argentina (Documento de Trabajo no 98) [Economics of Municipal Governments. Theory and Applications to Argentina (Paper No. 98)]. Universidad Nacional de La Plata. http://sedici.unlp.edu. ar/handle/10915/45923

Maskell, P. (2001). The firm in economic geography. 
org/10.1002/smj.2433

Wang, Y. y Poutziouris, P. (2010). Entrepreneurial risk taking: Empirical evidence from UK family firms. International Journal of Entrepreneurial Behaviour \& Research, 16(5), 370-388. http:// dx.doi.org/10.1108/13552551011071841

Weismeier-Sammer, D., Frank, H. y von Schlippe, A. (2013). Untangling 'Familiness' A Literature Review and Directions for Future Research. Entrepreneurship and Innovation, 14(3), 165-177. http://dx.doi.org/10.5367/ ijei.2013.0119

Wenzel, M., Stanske, S. y Lieberman, M. B. (2020). Strategic responses to crisis. Strategic Management Journal, 42(2), 016-027. http://dx.doi.org/10.1002/smj.3161

Williams, T., Gruber, D., Sutcliffe, K., Shepherd, D. y Zhao, E. Y. (2017). Organisational response to adversity: Fusing crisis management and resilience research streams. Academy of Management Annals, 11(2), 733-769. http:// dx.doi.org/10.5465/annals.2015.0134

Yin, R. (2003). Investigación sobre estudio de casos: diseño y métodos (2a ed.) [Case Study Research: Design and Methods (2nd ed. )]. Sage Publications.

Zellweger, T., Eddleston, K. y Kellermanns, F. (2010). Exploring the Concept of Familiness: Introducing Family Firm Identity. Journal of Family Business Strategy, 1(1), 54-63. https://doi.org/10.1016/j.jfbs.2009.12.003 